\title{
Crises experienced in church organizations: The case of Parklands Baptist Church Nairobi Kenya
}

\author{
Martin kuria
}

\begin{abstract}
This study evaluated crisis preparedness in churches and focused mainly on crisis communication in Parklands Baptist Church (PBC) in Nairobi, Kenya. The study's main objective was to find out the types of crises that have affected the church in the past 5 years. The study employed a descriptive research design. The study established that the church experiences crisis but mostly from a rare to often basis. A sizeable number of PBC congregants indicated to have observed different crises in the church. It was inferred that the church rarely communicates to inform about crises to its congregants and this would explain why most congregants in Churches held the belief that the church is rarely engulfed in crises.
\end{abstract}

Key words:- Crisis, Church, Congregants, Crisis Preparedness Communication

\section{INTRODUCTION}

To begin with, it is notably true that organizations are likely to go through a crisis at one point or another (Register \& Lakin, 2005). The church then is an organization that is not immune to crises. James and Gilliland (2013) define a crisis as a perception or an experience of an event or situation that is of great difficulty exceeding a person's current resources and coping mechanism. Crises are common phenomena in the church. For instance, the 1980's saw the fall of televangelists Jim Bakker and Jimmy Swaggart after the dent in their reputation brought suspicion upon their multimillion dollar ministries (and those of others). In 2007 a local pastor in Virginia Beach, in the United States of America was found guilty of embezzling \$ 125,000 dollars from his church as well as filling several false insurance claims (Bourne, 2007). Still in the same community of Virginia Beach, just a few months earlier a church was trying desperately to oust their pastor (Sabo, 2007). The squabble emerged from a host of grievances mostly brought by financial deals gone sour. Both of these stories were front page headliners to readers in Virginia community (Legg, 2008).

\section{LITERATURE REVIEW}

The literature reviewed details the crises raised in other churches such as the Catholic Church, which has not been spared either; in detail it is accused of having rampant pedophilia. The Vatican as well as the diocesan officials expressed concern for the assaulted children only after cases were exposed in the press. Not only did the church fail to show enough concern and empathy for the victims, but they engaged in finding scapegoats and blame games. The Church leaders implied that they were victimized and targeted by the media who they said were blowing the problem out of proportion. Although the Catholic Church proves itself as being able to plan and communicate during the crises it faces, it creates dissonance by attributing the crises contrary to what the church stakeholders expect (Adubato, 2014). The stakeholders expect the Catholic Church to own up that there is rampant pedophilia and also give an explanation as to what is being done about it. In related cases, a UK-based Winners Chapel church which has a large network in Kenya was accused of "cynical exploitation" in the UK. It had just received 16.7 million pounds (Ksh2.4 billion) in donations from followers who were told that God would give them riches in return. Bishop Oyedepo, who is the senior pastor, was accused of exploitation and is now under probe. The entire church is now at a crisis and is likely to lose followers based on these allegations (Kwama, 2014). In our local Kenyan situation many churches have been accused of commercialization of faith. Churches such as JIAM, Neno evangelism, Maximum miracles and Finger of God have all gone through devastating losses, after being faced with crises. Even when a crisis does not receive national attention, it is still likely to be detrimental to the reputation and viability of the church (Legg, 2008). Nyambura (2013) observes that the main threats to the church are fake pastors, greed, immorality, corruption and acts of terror. She illustrates with the case of Prophet Victor Kanyari who has been accused constantly of asking money as a form of a 'seed' to be planted so that God release miracles. Such individuals and their churches have not been seen to do much to restore the confidence and the trust that congregation, church investors, employees, church managers' other faith based institutions and the government may have lost in the institutions hit by crises. 


\section{METHODOLOGY}

This study employed a descriptive research design which is a plan, structure and strategy of collecting data in order to determine and report the way things are. It involved the use of a questionnaire and an interviews schedule to collect data. Kothari (2008) describes the descriptive survey design as ideal in situations where the researcher needs to describe characteristics as they are. A descriptive research is useful where the researcher needs to collect data for purposes of answering research questions concerning the current status of the subjects in the study (Gay, 1981). In this case the task of the study is to explore the status of crisis communication preparedness in Nairobi Baptist church.Robson (2002) asserts that descriptive studies are visible in researches concerning organizations and can be employed in both qualitative and quantitative approach to data collection. Kerlinger (1969) further asserts that descriptive studies are not only restricted to fact findings, but may often result in the formulation of important principles of knowledge and solution to significant problems. This implies that on using the descriptive design the researcher would be able to make generalizations to other churches on the usefulness of crisis management strategies. The research location is essential because it brings out certain elements of insight that inform more about the study (Kombo \& Tromp, 2011). The study was carried out in Nairobi, Kenya, and described the crisis preparedness of the Nairobi Parklands Baptist Church communications department. The church has an estimated 1348 congregants from various economic backgrounds. It draws the attention of faithful who work in a variety of professions. It commands a local presence in the media and it also appeals internationally through various media to various stakeholders. It is located at the central part of the nation's capital which means it meets very diverse needs and challenges from its congregants. The church therefore forms a good representation of an influential Kenyan church.Mugenda and Mugenda (2003) argue that, a researcher needs to pick a target population from which to generalize the results of a study. The population for this study was approximately 122 members. The congregants were grouped under different categories; gender, age groups of the church and the staff in various departments. Kombo and Tromp (2011) state that stratified random sampling involves dividing your population into homogeneous subgroups and then taking a simple random sample in each subgroup. The sample was selected in such a way as to ensure that certain subgroups in the population were represented in proportion to their number in the population. Before picking the desired subjects in the population, the subjects were selected in such a way that the existing subgroups in the population would be producing the sample. In this case the sampling frame involved a list of elements in the population which were selected in the following way: $10 \%$ of the population from the church management body, $10 \%$ of each of the following ministries: Golden Girls' ministry, Missions Ministry, Maturity Ministry, Benevolence ministry, Couples ministry and the Youth Ministry. Data collection occurred immediately after church service.

\section{FINDINGS}

The findings indicate that there were 79 respondents, $49.4 \%$ of them were male and $44.3 \%$ of them were female. In addition, the researcher sought to find out the respondents' age, $75.9 \%$ of the respondents were within age $15-30$. Only $7.6 \%$ were within age $35-40$ while $16.5 \%$ were age 40 and above. This study's objective one was to find out the nature of crisis that has affected the church in the past five years. Question item four which was a check list of the crises which might have been experienced by the congregants required the respondents to indicate on a three point scale the frequency of occurrence of the crises. The crises examined were as outlined by Coombs (2007) on crises that affect organizations. These are: The resignation of a church minister, the mismanagement of church finances, workplace violence, false rumors, damaging information about parklands Baptist church, church breakaway, death of a minister, sexual immorality claims on church officials, robbery and church bombings. $8.9 \%$ indicated that they had often experienced the resignation of a church minister. $17.7 \%$ have shown that they have rarely observed the resignation of a church minister. A majority of 69.6 had never observed the crisis of a resigning minister. Over 27\% indicated that the resignation of a church minister occurs rarely while others indicated it occurred often. The respondents were also asked whether they experienced mismanagement of church finances. The findings reveal that $70.9 \%$ of the participants indicated that they had never observed the mismanagement of church finances, however some of the $24 \%$ indicated to have observed the crisis on a rare and often basis. Regarding the occurrence of natural disaster in the church, the researcher asked the respondents to indicate the frequency of occurrence of the crisis. Some $94.9 \%$ of the respondents answered the question. $72.2 \%$ of respondents indicate that they had never experienced any natural disaster in the church. However, $22.8 \%$ of the respondents showed that some had experienced the disaster on rare and others on often occasions. Further, the researcher sought to find out whether work place violence occurred in the church. The respondents were asked to indicate if they had ever experienced crisis of work place violence Majority of the respondents comprising $83.5 \%$ indicated that they had never experienced the crisis of work place violence. However, some $20.2 \%$ revealed that they had experienced the crisis in church. A fifth of the respondents indicate church violence had occurred. In addition, the study investigated the occurrence of crisis of rumors in the church. Slightly over $51 \%$ reported that they had never experienced crisis of rumors in the church. On the other hand $22.8 \%$ and $21.5 \%$ reported to have experienced the crisis of rumors on a rare and 
often basis The researcher also sought to find out whether the Parklands Baptist church had ever experienced crisis related to Church break away. Most of the respondents $(64.6 \%)$ indicated that there had not been church break away, $25 \%$ revealed that they had observed crisis on a rare and often basis. The study also sought to find out whether the congregation had ever witnessed the death of a minister. A response rate of $89.9 \%$ was registered On the one hand, a $57.0 \%$ of the respondents indicated that they had never experienced the death of their church minister; on the other hand $33 \%$ revealed that they had experienced the death of a minister at Parklands Baptist Church.

The researcher also investigated whether the respondents had ever experienced a robbery crisis in the church. The response rate to this item was $97.5 \%$. Some $20.3 \%$ of the respondents showed they had experienced church robbery either on rare or often basis. Finally the researcher examined whether the church ever experienced church bombing related issues. The findings revealed that $83.5 \%$ indicated that terror attack related experiences had never occurred. However, Some 14\% indicated that church bombings experience had been noted on a rare and often basis. The researcher's interest was to find out the type of crises that had affected the church in the past. Some two ministry pastors and two finance officials were interviewed on the crises that had been experienced. It was reported that there was a transition that went wrong where the old team of pastors who led various ministries did not want to allow the new team to take over. So they were allowed to talk among themselves and also decide how they would release their roles and assist the new leaders to perform their duties smoothly. Since the issue was getting out of hand, the senior pastors came in to give directives that the old team should leave. The tussle was not addressed publicly in church neither were the members in various ministries addressed over the crisis affecting them. The ministry pastors also reported that leadership tussles surfaced often. They explained that the church has a constitution which has a leadership code of conduct that all leaders should subscribe to. It means that leaders will not just abide with the norm of work but also with the disciplinary measures that come with the code. During the interview there was no indication of a plan to communicate during crises, other than the code of conduct that has been put in place to guide on issues of conduct. Evidently there was some plan to avert crisis through the use of hierarchy of authority and the constitution' code of leadership. However, there are no crises communication plans for both internal and external publicThe deacons stated that solving crises depended on the crisis type, so the church allows professionals in the church to advise on what should be done. They gave the example of 2007- 2008 ethnic clashes; the church had to bring in professionals to deal with possible church divisions and emotional problems experienced by congregants after post-election violence had happened. The deacons cited that in most cases when a crisis occurs, pastors are considered to be the most credible in speaking to the church. In instances when the fault belongs to the church, the deacons stated that pastors take up the chance to apologize or justify the cause of the crisis. At times the church chooses to visit and show compassion by compensation and also ensuring that the people in the community feel that the church is with them. One of the crises that the church has faced recently was when two senior pastors lost their wives the previous almost at the same time. The communication team only prepared avenues of the announcements in the church but pastors and deacons arranged on special announcements of what should be said in the church and the communications team was excluded in advising on communicating about the crisis. The worship pastor also gave a description of how two years ago, Parklands Baptist Church band decided that it would not play its role in worship. The congregation had to be told that they needed to bear with the hitch and that they had to be led in acapella. The issue was handled at different leadership levels. Most people wanted to know why the band didn't play but the church seemed to select who to talk to. The reason or the attribution given towards the crisis was kept secret and the officials up to date have never explained why the band didn't play. Interviews with a youth pastors and a leader also reported that one of the major crisis faced mostly by the youth leadership is when the youth go for mission activities and the logistics do not work according to plan. The senior leaders as well as youth leaders convene a meeting earlier before a mission and involve parents through information sharing so that in cases of danger, the leadership is ready to communicate with parents. In this case crisis communication is practiced before and after a crisis has occurred but the strategy is usually spelled out earlier. In the case of post-election violence the church made an attempt to go to the congregation, talk to them and justify why crisis had occurred and how it had affected the congregation or its external stakeholders. The church management asked the congregants to raise support for the needy. The management also held talks with other churches and combined forces with them to raise support for the affected.

One of the other crises that were recalled was when two pastors almost around the same time resigned and went to work for other churches. It was very painful for the church to state that the pastors left the grand church because they found greener pastures. Loss was felt because some members defected from the church after their favorite pastors had resigned.

Another major crisis was when a worker had a master key for every office. He went stealing and there was a reported robbery. The man was dismissed from his job but no charges were filed against him. This case of a crisis was not communicated to the congregation even though precious items went missing.A pastor also recalled a robbery incident in the church, when robbers learned that money would only be deposited on a 
particular day of the week. This was a very painful time because the church lost millions of shillings that they had collected that particular week. Currently money is collected by courier services with armored vehicles guarded by the police immediately the offering is given, but in those times, money would be stored in safes. In this case the congregation was told that the crisis had occurred.

Data was gathered on financial crisis using interview method with two finance officers. It was reported that Parklands Baptist church had been invited for a mission to the prison. The team experienced a budgetary deficit that could not allow the visit. The budgetary allocation had been broken down into all activities that needed to be done throughout the year. Yet people in the church believed that there was normally little planning needed in executing missions. The congregation needed answers as to why the mission was not happening and it was very hard to explain the budgetary constraints especially when the mission could not be undertaken. Eventually the congregants were communicated to and they decided to give their own resources to facilitate the mission took place. In this particular case the communications office was available to assist in communicating to the congregants willing to go for the mission but they were not involved in explaining why this mission was not going to take place.

Recently partners from Japan gave money towards building a high school in one of the mission stations. They had supported the building of a nursery and primary school previously. The partners after disbursing money were waiting for the church to give a commitment that the building process had begun but it couldn't happen due to budgetary allocation problems. It was also clear that the community needed the school to be built as soon as possible since standard eight pupils in the community were depending on this project in order to begin their high school education. The crisis became escalated when the donors as well as the community, wanted to find out why the process of building the school hadn't begun and why the church could not give a commitment. To this time, the church has not managed to explain to the community and the Japanese donors the reason why the intended high school is yet to be constructed within the scheduled time. The communications department did not give $\mathrm{n}$ their expertise on what to tell the stakeholders. The church has also not been informed concerning this particular crisis.

The study found out that crises occurred in the church according however a minority ranging from 17 $40 \%$ pointed they had observed various crises happening in the church. The crises examined were the resignation of a church minister, the mismanagement of church finances, workplace violence, false rumors and damaging information, church breakaway, death of a minister, sexual immorality claims on church officials and robbery in the church. A majority of respondents interviewed ranging from $60-80 \%$ reported not having experienced the crisis. The lack of awareness can be attributed to the church's non written policies of selective communication, lack of a functional crisis communication office and the strategy of communicating to selective stakeholders only. This causes only a few members of the group to be aware. However, the percentages that are aware of the crisis are a sample of the larger church and thus translated to the whole church, the figures are significant.

\section{DISCUSSION}

The researcher found out that the church is always vulnerable to crisis as outlined by Coombs (2007) which could be natural disasters, rumors, workplace violence, technical error, and human errors. The following are some of the crises types that Parklands Baptist Church might have faced over time: resignation of ministers, mismanagement of church finances, natural disasters, work place violence, false rumors and damaging information, death of a church ministers or church officials and robbery in the church. The researcher also found out that the church does not have concrete crisis communication plans since the communication department is mostly used to build publicity for the institution rather than cater as crisis communication experts as well, therefore the church lacks the necessary crisis communication expertise that it needs. Conclusively, a majority of the stakeholders expressed room for improvement on how the church communicates and prepares for crisis. They failed to show total confidence in whether the church was entirely ready for any crisis that might occur.

\section{CONCLUSION}

Lamb and Mckee (2005) explain the system theory with emphasis of having a system that allows two way relationships between its management and stakeholders. The church in this case still does not have specialized means which allows for the system to listen to its stakeholders. If for instance the church management decides to be dictatorial whereby it only gives information for its own gain without maintaining balance or even consulting communication experts as well as various stakeholders, then the likelihood of its membership shrinking is likely to be quite high. Consequently, if the church creates a system of openness, preferably through public relations with the use of a team dealing with crisis communication working with the management there is likelihood that stakeholders will gain confidence in working with management and shrinking will be reduce. The findings indicate a likelihood of Parklands Baptist Church operating under a closed system. This is why a majority of congregants are not aware that crises are actually happening. 


\section{REFERENCES}

[1] Adubato, S. (2014). Communication crisis for the Catholic Church. Cacus Education Corporation. Retrieved from http://www.caucusnj.org/adubato/starledger/catholic-comm.aspx

[2] Bourne, D. (2007). Beach pastor charged with embezzling from church. Pilotonline.com Retrieved from http://hamptonroads.com/node/335721

Combs, T. (2012). Ongoing crisis communication: Planning managing and responding. Carlifornia Sage Publications, Inc

[3] Kwama, K. (2014, February 10). UK's Winners' Chapel at the center of newspaper probe. The Standard Xtra, p. 2. Retrieved from www.standardnews.co.ke

[4] Kothari, C. R, (2004) Research methodology: Methods and techniques (2 ${ }^{\text {nd }}$ eds.). New Delhi: New Age International Publishers.

[5] Kombo, D., \& Tromp, D. (2006). Proposal and thesis writing: An introduction. Nairobi: Paulines Publications Africa.

[6] Legg, L. K. (2008). Crisis communication in the local church: A macro look at the church crises and application of chaos theory. Regent University. Virginia, USA. Retrieved from http://gradworks.umi.com/33/42/3342616.html

[7] Mugenda, G. A. (2008). Social science research: Theory and principles. Nairobi, Kenya : Kijabe Printing Press.

[8] Nyambura, V. (2013, August 20). Fake miracles and prosperity gospel flourishing in Kenya. Nairobiexposed.Retrievedfromhttp://www.nairobiexposed.com/2013/08/20/fake-miracles-and-prosperitygospel-flourishing-in-kenya/

[9] Robson, C. (2002). Real world research ( $2^{\text {nd }}$ ed.). Oxford: Blackwell.

[10] Register, M., \& Larkin, J. 2005 Risk issues and crisis management: A casebook of best practice. London: Kogan

[11] Sabo, M. (2007, April 3). Spirit moving pastor, flock in different directions. Daily Press. Retrieved from http://articles.dailypress.com 